\title{
A Review on Medicinal Plants Withania somnifera and Nyctanthes arbortristis: Boosting of Immune System During SARS-CoV-2
}

\author{
Minakshi Padhy 1,* (D) \\ 1 Department of Chemistry, Siksha 'O' Anusandhan ( Deemed to be University), Khandagiri, Bhubaneswar- 751030 India \\ * Correspondence: moon.94371@gmail.com;
}

Scopus Author ID 57218314781

Received: 5.07.2020; Revised: 7.08.2020; Accepted: 10.08.2020; Published: 15.08.2020

\begin{abstract}
The worldwide epidemic of SARS-CoV-2 has created a panic situation in human beings. Covid-19 viruses spread infections into the specific human cells through cell-surface receptor ACE2 and start viral replication speedily inside the human body. The action of antibodies can reduce the entry of the virus into the cell by binding with the spike head and prevent to connect with ACE2 receptor. Many types of research are going to find the exact vaccine to control the spread of this virus. But still, now there is no vaccine and specific medicine invented still now, which is a big headache across the world. At this pandemic period, boosting of the immune system is the best way to fight against this virus. From ancient times, Ayurved is known as the best immune booster for animals and mammals. The herbal plants, such as Nyctanthes arbor-tristis L. And Withania somnifera has excellent immunomodulatory, anti-inflammatory, antitumor, inhibition of oxidants, carcinopreventive properties with important chemicals like Withaferins, different alkaloids, steroids, amino acids. This review is based on a brief discussion of the pharmacological behaviors, active ingredients, and potential therapeutic applications of these medicinal plants.
\end{abstract}

Keywords: SARS-CoV-2; Ayurvedic; Nyctanthes arbor-tristis L.; Withania somnifera; Immune system.

(0) 2020 by the authors. This article is an open-access article distributed under the terms and conditions of the Creative Commons Attribution (CC BY) license (https://creativecommons.org/licenses/by/4.0/).

\section{Introduction}

The super community spreader SARS-CoV-2 (acute respiratory syndrome corona-virus 2 has affected over worldwide. This coronavirus pandemic is the defining health and wealth crisis of our time and the greatest challenge we have faced since world war two. To date, there is no specific drug and vaccines registered to combat the disease. This novel SARS-CoV-2 is also known as COVID-19. This COVID-19 patient is suffering from fever, Cough, Tiredness, shortness of breath or difficulty breathing, and other symptoms, like blue lips or face, persistent chest pain or pressure, heart attack, loss of taste or smell, etc. These can cause diseases associated with the central nervous system, respiratory problems (upper and lower), and gastrointestinal-tract infections [1]. This virus infection is very dangerous for people having diabetes, kidney, and heart diseases. During a viral infection, antiviral therapy is based on the attacking way of the virus into the host cell [2]. Coronaviruses spread infections into specific human cells through cell-surface receptors. The entry of the virus can be secured by targeting the viral receptor-binding site with neutralizing antibodies (nAbs). The surface of the Coronavirus is surrounded by many spike proteins. The entry of the virus is interposed by the 
Receptor Binding Domain (RBD) of the spike head(S1, S2), which attaches to the host cell receptor Angiotensin-Converting Enzyme 2 (ACE2). After the connection between the virus and the receptor has been established, the human body activates the TMPRSS2 enzyme. The TMPRSS2 enzyme is a protein cutting enzyme that helps to cut the head of the spike, and the structure of the virus begins to change. In this process, the membranes of the virus and the cell come very closer, and the entry of the virus into the cell takes place by the endocytosis process [3]. The action of antibodies can reduce the entry of the virus into the cell by binding with the spike head and prevent to connect with the ACE2 receptor. The immune system of our body plays an important role in producing antibodies on the detection of antigens. To reduce spreading and fast rehabilitation, many types of research are going on. In this current study, the priority is given to emphasize the immune system of the human body to fight against this COVID-19 pandemic period. The different kinds of concepts to increase the immunity and resistance power of the body to fight with many diseases is Ayurveda that is widely used in ancient times across the world. According to Ayurveda, the balancing of Vayu, pitta, and kaf plays an important role in our body. Imbalance of these three arises many diseases and decreases our immunity power. The immune system is the capacity of our body that protects us against microbes.

There are remarkable benefits of Ayurveda in India and also worldwide. Many parts of several plants are used as medicines and to increase immunity from ancient days. Villagers of India mainly use many types of medicinal plants to cure several diseases, even for cancer, diabetes, malaria, cough, common cold, and viral fevers, etc. Many types of plant products are used for various diseases like Aswagandha (Withania somnifera), parijat (Nyctanthes arbortristis L.), Tulsi, Turmeric, Black pepper, etc. Recently, the researchers found the key role of Withanone (Wi-N) present in Withania somnifera to block the viral replication [4].

In many parts of India, people are using Nyctanthes arborists L. leaf to cure large no. of diseases like diabetes, flu, even for malaria fever, cancer, and HIV. Many researches were done to know the benefits and increment of immunity power by consuming leaf of Nyctanthes arbor-tristis $L$. [5]. This tree is generally $8-10 \mathrm{~m}$ height, which does not require any special caring and can be planted in any place. Harshringar, the common name of Nyctanthes arbortristisis belongs from Oleaceae family. The name Nyctanthes is derived from the Greek words 'Nykhta' and 'anthos' means "Night Flowering". This tree is known by several names in various states of India like Night-flowering Jasmine, Harshringar, Seoli, Parijataka, Sephalika, etc. The leaves are generally opposite, 2.4-4.8 inch long and 0.78-2.56 inches broad, with an entire margin. The pleasant smelled flowers are orange centered with a 5-8 lobed white corolla. The loamy soils are perfect for the healthy growth of this plant. This plant needs an environment differing from partial shade-full sunlight and requires a frequent supply of water. Flowering usually takes place from the month of July- October. All the parts of this plant are very advantageous in medicinal chemistry.

Withania somnifera (Ashwagandha) is also a good medicinal plant that can boost our immune system as well as lower the blood pressure and help to calm the brain. It Is also known as Winter Cherry, Punir, Ghodakun, Fatarfoda, Asgund, Chirpotan, etc. This can be used for a longer time by all age-group and both genders as well as at the time of pregnancy with no sideeffects [6]. Withania somnifera, commonly known as Ashwagandha, Winter cherry, Withania is a small woody shrub belongs to the Solanaceae family. This can grow about 2 feet in height and generally found in Africa, the Mediterranean, and drier parts of India. This shrub has stout, fleshy roots, simple, ovate opposite leaves, and flowers inconspicuous, greenish or lubrid- 
yellow, in axillary, umbellate cymes. The roots are very useful parts and used as medicines. All the Parts (Whole plant, roots, leaves, stem, green berries) of this medicinal shrub are also valuable. Table 1 shows the taxonomical classification for both Nyctanthes arbortristis sand Withania somnifera.

Table 1. Taxonomical classification for both Nyctanthes arbortristis L. and Withania somnifera.

\begin{tabular}{l|l|l|l|l|l|l} 
Botanical name & Kingdom & Eudicots Division & Order & Family & Genus & species \\
\hline $\begin{array}{l}\text { Nyctanthes arbor- } \\
\text { tristis L. }\end{array}$ & Plantae & Angiosperm & Lamiales & Oleaceae & Nyctanthes & N. arbortristis \\
\hline $\begin{array}{l}\text { Withania somnifera } \\
\text { (Ashwagandha) }\end{array}$ & Plantae & Angiosperm & Tubiflorae & Solanaceae & Withania & Somnifera Dunal
\end{tabular}

\section{Chemical constituents and importance}

Table 2 shows the useful chemical constituents present in both the plants. The extraction of Nyctanthes arbor-tristis L. seeds with ethyl Acetate (Ny-El) has $206.81 \pm 1.11$ $\mathrm{mg}$ of total phenolic content, excellent scavenging action on DPPH (2, 2-diphenylpicrylhydrazyl), i.e., IC50 $459.91 \pm 1.40 \mu \mathrm{g} / \mathrm{mL}$, hydroxyl (IC50 $363.32 \pm 1.58 \mu \mathrm{g} / \mathrm{mL}$ ), nitric oxide (IC50 $545.03 \pm 1.69 \mu \mathrm{g} / \mathrm{mL}$ ) and superoxide (IC50 $338.82 \pm 1.72 \mu \mathrm{g} / \mathrm{mL}$ ) groups, and high reducing power [7]. The seeds and the leaves are important parts of this plant contain iridoid-glycosides. The flower also has medicinal properties and the presence of essential oil like jasmine. The leaf contains mannitol, beta- amyrin, beta-sitosterol, benzoic acid, astragalin, nicotiflorin, and acids like oleanolic and nyctanthic.

Withania somnifera roots are an important part of this plant and widely used as medicines [8]. The roots contain different types of alkaloids, amino acids, steroids, and reducing sugars as well as glycosides. Withania somnifera roots, there are present $21-25 \%$ of crude fiber, $6.09-9.46 \mathrm{mg} / \mathrm{g}$ of starch, $0.39-0.82 \mathrm{mg} / \mathrm{g}$ of tannins, various minerals such as potassium $(\mathrm{K})$, manganese $(\mathrm{Mn})$, sodium $(\mathrm{Na})$, iron $(\mathrm{Fe})$, zinc $(\mathrm{Zn})$, etc., $2.52-9.52 \mathrm{mg} / \mathrm{g}$ of total sugars, $0.15-2.10 \mathrm{mg} / \mathrm{g}$ of reducing-sugars and $2.37-7.62 \mathrm{mg} / \mathrm{g}$ of non-reducing-sugars [9].

Table 2. Phytochemistry of Nyctanthes arbor-tristis L. and Withania somnifera.

\begin{tabular}{l|l} 
Plants & Presence of chemical constituents \\
\hline Nyctanthes arbor-tristis L. & $\begin{array}{l}\text { Flavonoids; Steroids; Tannins; Alkaloids and Glycosides; D(-)mannitol; beta-sitosterole; } \\
\text { Flavanol-glycosides (like- Astragaline, Nicotiflorin, methyl salicylate and acids such as } \\
\text { Oleanolic acid, ascorbic acid, Nyctanthic acid, tannic acid, etc. ) [10]. }\end{array}$ \\
\hline Withania somnifera & $\begin{array}{l}\text { Alkaloids- isopellertierine, anferine; steroidal compounds and steroidal-lactones (like- } \\
\text { ergostane, withaferin A, withanolides A-y); withasomniferin A, withasomidienone; } \\
\text { withasomniferols A-C; acylsteryl glucosides comprising sitoindosides VII and VIII; } \\
\text { reducing-sugar, and different amino acids ( aspartic acid, proline, tyrosine, alanine, } \\
\text { glycine, glutamic acid, cystine, tryptophan) [11]. }\end{array}$
\end{tabular}

\subsection{Alkaloids.}

Alkaloids are obtained from various plants. Alkaloids are physiologically active basic nitrogenous compounds. The Raw plants contain most of the alkaloids in the form of organic acids (salts). Alkaloids have various pharmacological activities, including antimalarial, antiasthma, anticancer, cholinomimetic (e.g., galantamine), vasodilatory, antiarrhythmic, etc. [12]. 


\subsection{Flavanol-glycosides.}

Flavonoids are generally obtained from plants. Besides antioxidant behavior, flavonoids have many therapeutic activities such as antiallergic, antiviral, anticancer, antiinflammatory, etc. The anti-inflammatory activity of flavonoids in the management of inflammatory disorders behaves as cytokine modulators. Other than these, it is a beneficial drug to cure oxidative stress, wound (scratch), inflammation, aging, cancer, arteriosclerosis, and ischemic and neurodegenerative disorders. It is proven from epidemiological studies that the regular consumption of flavonoids reduces the mortality, hyperpiesis, risk of heart-related problems as well as cure coronary diseases [13].

\subsection{D(-)mannitol.}

Mannitol has a great property that is crudely consumption from the renal tubule and freely strained by the glomerulus. So it causes an enhancement in osmolarity of the glomerular filtrate, which limits the tubular consumption of water, sodium, chloride, and additional solutes as well as promotes diuresis. Except for this, mannitol also enhances blood plasma osmolarity and the flow of water from tissues into interstitial fluid and plasma [14].

\subsection{Beta-sitosterol.}

Beta-sitosterol is known as "plant sterol ester" as it is found in plants. This is an essential compound that mostly used in medicines and similar to cholesterol. It helps to reduce cholesterol levels by limiting the absorption of cholesterol by the body. It also has inflammation property that binds to the prostate to help reduce swelling [15].

\subsection{Withaferin A.}

The withaferin A (WFA) is the most abundant biological active constituent in Withania somnifera plant with highly oxygenated withanolide. WFA stimulates osteoblast proliferation, mineralization, and stimulus of ALP (Alk Phos.) action. WFA has the property to inhibit directly osteoclastogenesis and indirectly generate osteoblast to control osteoclastogenesis [16].

\subsection{Amino acids.}

Amino acids are the "building blocks" of protein as it helps to produce proteins. The amino acids cannot be manufactured by the body sufficiently. So, from outside supplements, the human body can get different amino acids. Enzymes and hormones are made by utilizing amino acids that support the biochemical activities and influences the body's metabolism. Amino acids are also used to make hemoglobin and antibodies that are helping to oxygen transfer inside the body and fight infections by increasing the immunity [17].

\section{Immunomodulators activities}

Clinically, there are three types of immunomodulators, like immune adjuvants, immunostimulants, and immunosuppressants. Immunoadjuvants are utilized to improve the potency of vaccines and, therefore, could be considered specific immune stimulants. It is suggested that immunomodulators can be used as selectors among cellular and humoral 
immune helper T1 (Th1) T2 (Th2) cells, immunology activities, and reagent IgE vs. IgG type immune responses causing a big issue for design vaccines [18].

The non-specific nature of Immunostimulants is playing a key role by enhancing the resistance of a body against various infections. They can behave as adaptive and also inborn (natural) immune-responses. The immunostimulants are expected to serve to prevent diseases and promote immunity in a healthier body. That means they act as immunopotentiators by increasing the primary level of immune responses [19].

Immunosuppressants are a heterogeneous class of drugs on the basis of both structural and functional manners. These are sometimes simultaneously regulated in combination with autoimmune diseases and regimens to treat different rejection of organ transplantation [20]. Many types of medicinal plants are employed to increase the resistance power of animals and mammals, which is traditionally known as 'Rasayana' in India. The interesting medicinal properties of these plants have attracted many researchers worldwide.

Nyctanthes arbor-tristis $L$. is a medicinal plant that has anticancer [21], immunostimulant [22], hepatoprotective [23], antiviral [23], antimicrobial and antifungal [24], anti allergy [25], anti-diabetic [26], anticholinesterase [27] properties against several diseases. Nyctanthes arbor-tristis L. has the capacity to stimulate the immune-system, pretends both humoral and cell-mediated immunities as have been analyzed its effect in the indirect hemagglutination test and serum immunoglobulin levels [28]. The leaf juice of this plant is used to cure many diseases like- to get rid of roundworms and threadworms, to treat loss of appetite and nausea, liver and bile-duct related diseases, piles, chronic disorders and fever-like malarial, obstinate the irritation of the sciatic nerve, rheumatoid arthritis diseases, and as a diaphoretic. Garden- fresh leaf juice, honey, and common salt mixed doses have been recommended to be secure laxative for infants. Two-ounce infusion doses are beneficial in fever and rheumatic diseases as a diuretic and medicinal drug. For snakebite and bronchitis treatment, the bark is very useful. The Indian tribal people utilize different parts of Nyctanthes arbortristis to get a cure from cough, hiccup, dysentery, snakebite, and sores. To destroy parasitic worms (anthelmintic), this plant is used widely in Nepal. Along with the above activities, Nyctanthes arbortristisis is also used as immunotoxic, antiallergic, antihistaminic, purgative, antibacterial, and ulcerogenic activities [29].

Withania somnifera is a very attractive medicinal plant with many healing properties. In other words, it is a blessing plant for human life. Withania somnifera is very useful on the bone marrow cellularity and a-esterase positive cell, on circulating antibody titer, on antibodyproducing cells, on phagocytic action of peritoneal macrophages. The extraction of $W$. somnifera is noticed that it increases the circulation of antibody titer and cells that form antibodies. It is also proved that by treating animals with Withania, there is an outstanding growth of the bone-marrow cells [30]. Withanolides contain many activities like antiinflammatory and analgesic because of cyclooxygenase- 2 diffidence behavior. The use of this plant also increases the 'NO' (nitric oxide) synthetase activity of the macrophages. That increases the CMI (Cell-Mediated Immune) response due to the enhancement of the microbial destroying ability of the immune cells. W. somnifera, a glycol protein known as WSG (Glycowithanolides) is also liable for anti-microbial activities [31]. Protein and the bodyweight increase, when Withania somnifera is supplemented with milk. This plant is a treasure of nature due to it's antistress; radio-sensitization activity, advantageous effects on the cardiovascular system and sex hormones; therapeutic behaviors upon Neuro-degenerative symptoms, and poisons (like- toxins, snake venom, and chemicals). According to charak-sahmita (a Sanskrit 
text on Ayurveda), Withania somnifera has Immunostimulatory, anti-inflammatory, antistress, anti-rheumatic properties [32]. Recently, the researchers attacked the leading SARS-CoV-2 enzyme for breaking up proteins, identified as the Main protease (Mpro). Mpro plays an important role in moderating viral replication. Withanone (Wi-N) obtained from Withania somnifera and Caffeic Acid Phenethyl Ester (CAPE), an active constituent of New Zealand Propolis, has the potential to interact with and block the activity of Mpro.

\section{Other immunomodulatory herbal plants}

Worldwide, there are a vast number of medicinal plants that are used to cure many diseases and enhance the immune system. Table 3 represents some plants that have high Immunomodulators activities other than Nyctanthes arbor-tristis L. and Withania somnifera.

Table 3. Medicinal plants that are used as Immunomodulators.

\begin{tabular}{l|l|l|l} 
Sl.No. & Botanical name & Common name & Properties \\
\hline 1 & Allium Sativum & Lahsuna & Antibacterial, Antiviral [33] \\
\hline 2 & Desmodium gangeticum & shalaparni & Antiviral, Antiasthamatic [34] \\
\hline 3 & Terminalia belerica & Bahera & Immunostimulant [35] \\
\hline 4 & Tinospera cordifolia & Guduchi & Immunostimulant, anti-rheumatic, antiallergic [36] \\
\hline 5 & Abrus precatorius & Gunja & Immunostimulant [37] \\
\hline 6 & Allbizzia Lebbeck & Shirisha & Immunostimulant [38] \\
\hline 7 & Andrographis paniculata & kalmegh & Immunostimulant [39] \\
\hline 8 & Aristolochia Indica & Isharmul & Immunostimulant [40] \\
\hline 9 & Berberis aristata & Dar-hald & Immuno-suppressor,antibacterial [41] \\
\hline 10 & Catharanthas roseus & Sada Bahar & Immunostimulant, Induces antibody production [42] \\
\hline 11 & Clitoria ternatea & Aparajita & Immunostimulant [43] \\
\hline 12 & Cymbopogon martini & Gandh & Immunostimulant [44] \\
\hline 13 & Hyoscyamus niger & parsikaya & Immunostimulant [45] \\
\hline 15 & Nardostachys jatamansi & Jatamansi & Immunostimulant [46] \\
\hline 16 & Ocimum sanctum & Tulsi & $\begin{array}{l}\text { Antiviral, } \\
\text { inflammatifungal, }\end{array}$ Antiasthmatic, \\
\hline 17 & Piper betel & anti- \\
\hline 18 & Claviceps purpurea & Ergot & Antiviral, antiseptic [48] \\
\hline 20 & Phellodendron amurense & Amur cork tree & Immunosuppressant [51] \\
\hline 21 & Dioscorea japonica & Japanese mountain yam & Immunostimulant [52] \\
\hline 22 & Boerhaavia diffusa & punarnava & Immunomodulator [53] \\
\hline 23 & Acacia catechu & Senegalia catechu & cell-mediated, humoral immunity [54] \\
\hline 24 & Jatropha curca sL. & Barbados nut & Immunomodulator [55] \\
\hline 25 & Achillea wilhelmsii & Achillea wilhelmsii & Immunomodulatory [56] \\
\hline 26 & $\begin{array}{l}\text { Picrorhiza } \\
\text { Scrophulariiflora }\end{array}$ & $\begin{array}{l}\text { Sicrorhiza } \\
\text { Scrophulariiflora }\end{array}$ & Immunostimulatory [57] \\
\hline 27 & Schisandra arisanensis & Schisandra & Immunomodulatory [58] \\
\hline 28 & Curcuma longa & Turmeric & Immunostimulatory, anti-inflammatory [59]
\end{tabular}

\section{Conclusions}

The extraction of different plants and herbs are very helpful in obtaining a higher protective antibody against various infections and also to produce and develop more productive cell mediate immune system. These are beneficial to protect from different bacterial, viral, and other infections with no/lower toxic property. So that Herbal formulation is the best way for a positive immunomodulator. These drugs are very high potential therapeutic with high efficacy, low toxicity, and cost-effectiveness. Nyctanthes arbor-tristis L. and Withania somnifera have excellent immunomodulatory, anti-inflammatory, antitumor, inhibition of oxidant, carcinopreventive properties with important chemicals like Withaferins, different alkaloids, steroids, amino acids. These are secure the body from cumulative damage by oxidations and diseases. In conclusion, this research paper gives therapeutic awareness about Withania somnifera, 
Nyctanthes arbor-tristis L., and other medicinal plants, which are used widely across the world. Although, the conclusion from this review is utterly convenient for the utilization of these plants as immunomodulators and benign medicinal agents and to improve the immune system during COVID-19.

\section{Funding}

This research received no external funding.

\section{Acknowledgments}

This research has no acknowledgment.

\section{Conflicts of Interest}

The authors declare no conflict of interest.

\section{References}

1. Zhang, J.; Zhou, L.; Yang, Y.; Peng, W.; Wang, W.; Chen, X. Therapeutic and triage strategies for 2019 novel coronavirus disease in fever clinics. The Lancet Respiratory Medicine 2020, 8, e11-e12, https://doi.org/10.1016/S2213-2600(20)30071-0.

2. Bupp, K.; Roth, M.J. Alteration and Analyses of Viral Entry with Library-Derived Peptides. In Advances in Virus Research, Academic Press: Volume 65, 2005; pp. 147-172, https://doi.org/10.1016/S00653527(05)65005-1.

3. Adedeji, A.O.; Sarafianos, S.G. Antiviral drugs specific for coronaviruses in preclinical development. Current Opinion in Virology 2014, 8, 45-53, https://doi.org/10.1016/j.coviro.2014.06.002.

4. Balkrishna, A.; Pokhrel, S.; Singh, J.; Varshney, A. Withanone from Withania somnifera May Inhibit Novel Coronavirus (COVID-19) Entry by Disrupting Interactions between Viral S-Protein Receptor Binding Domain and Host ACE2 Receptor. In Review 2020, https://doi.org/10.21203/rs.3.rs-17806/v1.

5. Mousum, S.A.; Ahmed, S.; Gawali, B.; Kwatra, M.; Ahmed, A.; Lahkar, M. Nyctanthes arbor-tristis leaf extract ameliorates hyperlipidemia- and hyperglycemia-associated nephrotoxicity by improving antioxidant and anti-inflammatory status in high-fat diet-streptozotocin-induced diabetic rats. Inflammopharmacology 2018, 26, 1415-1428 https://doi.org/10.1007/s10787-018-0497-6.

6. Abu Bakar, M.H.; Azmi, M.N.; Shariff, K.A.; Tan, J.S. Withaferin A Protects Against High-Fat DietInduced Obesity Via Attenuation of Oxidative Stress, Inflammation, and Insulin Resistance. Applied Biochemistry and Biotechnology 2019, 188, 241-259, https://doi.org/10.1007/s12010-018-2920-2.

7. Vajravijayan, S.; Udayakumar, M.; Brabakaran, A.; Nallamuthu, T. Article: Anti-inflammatory, Antioxidant and Free Radical Scavenging Activities of Nyctanthes Arbor-Tristis Linn. Seed Extract Under In Vitro. Scholars Academic Journal of Biosciences. 11/2013. Scholars Academic Journal of Biosciences 2013, 1, 242-250.

8. Alam, N.; Hossain, M.; Mottalib, M.A.; Sulaiman, S.A.; Gan, S.H.; Khalil, M.I. Methanolic extracts of Withania somnifera leaves, fruits and roots possess antioxidant properties and antibacterial activities. BMC Complementary and Alternative Medicine 2012, 12, 175, https://doi.org/10.1186/1472-6882-12-175.

9. Gulati, S.; Madan, V.; Singh, S.; Singh, I.; Dusyant. Chemical and Phytochemical Composition of Ashwagandha (Withania somnifera L.) Roots. Asian Journal of Chemistry 2017, 29, 1683-6, https://doi.org/10.14233/ajchem.2017.20536.

10. Sah, A.; Verma, V. Phytochemicals and Pharmacological Potential of Nyctanthes arbortristis: A Comprehensive Review. International Journal of Research in Pharmaceutical and Biomedical Sciences 2012, 3 .

11. Gulati, S.; Madan, V.; Singh, S.; Singh, I.; Dusyant. Chemical and Phytochemical Composition of Ashwagandha (Withania somnifera L.) Roots. Asian Journal of Chemistry 2017, 29, 1683-6, https://doi.org/10.14233/ajchem.2017.20536.

12. Lu, J.J.; Bao, J.L.; Chen, X.P.; Huang, M.; Wang, Y.T. Alkaloids Isolated from Natural Herbs as the Anticancer Agents. Evidence-Based Complementary and Alternative Medicine 2012, 2012, https://doi.org/10.1155/2012/485042.

13. Shukla, R.; Pandey, V.; Vadnere, G.P.; Lodhi, S. Chapter 18 - Role of Flavonoids in Management of Inflammatory Disorders. In: Bioactive Food as Dietary Interventions for Arthritis and Related Inflammatory Diseases (Second Edition). Watson, R.R.; Preedy, V.R. Eds. Academic Press: 2019; pp. 293-322, https://doi.org/10.1016/B978-0-12-813820-5.00018-0. 
14. Nissenson, A.R.; Weston, R.E.; Kleeman, C.R. Mannitol. West J Med 1979, 131, 277-84.

15. Valerio, M.; Awad, A.B. $\beta$-Sitosterol down-regulates some pro-inflammatory signal transduction pathways by increasing the activity of tyrosine phosphatase SHP-1 in J774A.1 murine macrophages. International Immunopharmacology 2011, 11, 1012-1017, https://doi.org/10.1016/j.intimp.2011.02.018.

16. Khedgikar, V.; Kushwaha, P.; Gautam, J.; Verma, A.; Changkija, B.; Kumar, A.; Sharma, S.; Nagar, G.K.; Singh, D.; Trivedi, P.K.; Sangwan, N.S.; Mishra, P.R.; Trivedi, R. Withaferin A: a proteasomal inhibitor promotes healing after injury and exerts anabolic effect on osteoporotic bone. Cell Death \& Disease 2013, 4, e778-e778, https://doi.org/10.1038/cddis.2013.294.

17. Blomstrand, E. Amino acids and central fatigue. Amino Acids 2001, 20, 25-34, https://doi.org/10.1007/s007260170063.

18. Enayat, N.; Jordan Ari, S.; Bhagirath, S. Therapeutic Benefits of Regulating Inflammation in Autoimmunity. Inflammation \& Allergy - Drug Targets (Discontinued) 2008, 7, 203-210, https://doi.org/10.2174/187152808785748155.

19. Kumar, D.; Arya, V.; Kaur, R.; Bhat, Z.A.; Gupta, V.K.; Kumar, V. A review of immunomodulators in the Indian traditional health care system. Journal of Microbiology, Immunology and Infection 2012, 45, 165184, https://doi.org/10.1016/j.jmii.2011.09.030.

20. Kumar, D.; Arya, V.; Kaur, R.; Bhat, Z.A.; Gupta, V.K.; Kumar, V. A review of immunomodulators in the Indian traditional health care system. Journal of Microbiology, Immunology and Infection 2012, 45, 165184, https://doi.org/10.1016/j.jmii.2011.09.030.

21. Shrivastava, R.; Bharadwaj, A.K. Nyctanthes arbortristis an Important Medicinal Plant of Madhya Pradesh State-A Review. UK Journal of Pharmaceutical Biosciences 2018, 6, https://doi.org/10.20510/ukjpb/6/i6/179227.

22. Rathee, J.S.; Hassarajani, S.A.; Chattopadhyay, S. Antioxidant activity of Nyctanthes arbor-tristis leaf extract. Food Chemistry 2007, 103, 1350-1357, https://doi.org/10.1016/j.foodchem.2006.10.048.

23. Srivastava, P. Nyctanthes arbor-tristis: A Wonder Indian Herbal Drug Needs Healthcare Attention. Biomedical Journal of Scientific \& Technical Research 2018, 5, https://doi.org/10.26717/BJSTR.2018.05.001199.

24. Patil, M.; Khan, A. Antibacterial Activity Of Leaves Of Nyctanthusarbor-Tristis L, Hibiscus Rosa-Sinensis L. And Sapindus Emerginatus Vahl. Science Park Research Journal 2015, 2, 1-05.

25. Kalyana Sundaram, I.; Sarangi, D.D.; Sundararajan, V.; George, S.; Sheik Mohideen, S. Poly herbal formulation with anti-elastase and antioxidant properties for skin anti-aging. BMC Complementary and Alternative Medicine 2018, 18, 33-33, https://doi.org/10.1186/s12906-018-2097-9.

26. Mathur, C.; Gupta, R. A review on medicinal plants of rajasthan having antidiabetic activity. Asian Journal of Pharmaceutical and Clinical Research 2018, 11, 33, https://doi.org/10.22159/ajpcr.2018.v11i12.28176.

27. Pattanayak, C.; Datta, P.P.; Chauhan, A.K.; Firdoush, K.A.; Prasad, A.; Panda, P. Hypoglycemic effect of Nyctanthes arbor-tristis leaf extract on Alloxan induced Diabetic rabbits. American Journal of PharmTech Research 2012, 2, 380-387.

28. Godse, C.S.; Tathed, P.S.; Talwalkar, S.S.; Vaidya, R.A.; Amonkar, A.J.; Vaidya, A.B.; Vaidya, A.D.B. Antiparasitic and disease-modifying activity of Nyctanthes arbor-tristis Linn. in malaria: An exploratory clinical study. Journal of Ayurveda and Integrative Medicine 2016, 7, 238-248, https://doi.org/10.1016/j.jaim.2016.08.003.

29. Agrawal, J.; Pal, A. Nyctanthes arbor-tristis Linn-A critical ethnopharmacological review. Journal of Ethnopharmacology 2013, 146, 645-658, https://doi.org/10.1016/j.jep.2013.01.024.

30. Davis, L.; Kuttan, G. Immunomodulatory activity of Withania somnifera. Journal of Ethnopharmacology 2000, 71, 193-200, https://doi.org/10.1016/S0378-8741(99)00206-8.

31. Saggam, A.; Tillu, G.; Dixit, S.; Chavan-Gautam, P.; Borse, S.; Joshi, K.; Patwardhan, B. Withania somnifera (L.) Dunal: A potential therapeutic adjuvant in cancer. Journal of Ethnopharmacology 2020, 255, https://doi.org/10.1016/j.jep.2020.112759.

32. Gupta, G.; Rana, A.C. Withania somnifera (Ashwagandha): A Review. Pharmacogn Rev 2007, 1, 129-36.

33. Kuete, V. Chapter 15-Allium sativum. In: Medicinal Spices and Vegetables from Africa. Kuete, V, editor. Academic Press; 2017; pp. 363-77, https://doi.org/10.1016/B978-0-12-809286-6.00015-7.

34. Singh, S.; Parmar, N.; Patel, B. A review on Shalparni (Desmodium gangeticum DC.) and Desmodium species (Desmodium triflorum DC. \& Desmodium laxiflorum DC.) - Ethnomedicinal perspectives. Journal of Medicinal Plants Studies 2015, 38, 38-43.

35. Sabu, M.C.; Kuttan, R. Antidiabetic and antioxidant activity of Terminalia belerica. Roxb. Indian journal of experimental biology 2009, 47, 270-275.

36. Saha, S.; Ghosh, S. Tinospora cordifolia: One plant, many roles. 2012, 31, 151-159, https://doi.org/10.4103/0257-7941.107344.

37. Das, S.; Bhakta, S. The medicinal values of Abrus precatorius: a review study. JABET 2020, 3, 84-91, https://doi.org/10.5455/jabet.2020.d111.

38. Warrier, K. Albizia lebbeck. 2010; pp. 79-92.

39. Okhuarobo, A.; Ehizogie Falodun, J.; Erharuyi, O.; Imieje, V.; Falodun, A.; Langer, P. Harnessing the medicinal properties of Andrographis paniculata for diseases and beyond: a review of its phytochemistry and 
pharmacology. Asian Pacific Journal of Tropical Disease 2014, 4, 213-222, https://doi.org/10.1016/S22221808(14)60509-0.

40. Kuo, P.C.; Li, Y.C.; Wu, T.S. Chemical Constituents and Pharmacology of the Aristolochia ( mădōu ling) species. J Tradit Complement Med 2012, 2, 249-66, https://doi.org/10.1016/s2225-4110(16)30111-0.

41. Kuete, V. 21-Health Effects of Alkaloids from African Medicinal Plants. In: Toxicological Survey of African Medicinal Plants. Kuete, V. editor. Elsevier; 2014, pp. 611-33, https://doi.org/10.1016/B978-0-12-8000182.00021-2.

42. Pattanayak, S. Use of succulent bio-medicines to control COVID-19. 2020.

43. Amol, P.; Vijay, R. Clitoria ternatea Linn.: An overview. International Journal of Pharmaceutical Research 2011, 3, 20-3.

44. Murbach Teles Andrade, B.F.; Conti, B.J.; Santiago, K.B.; Fernandes Júnior, A.; Sforcin, J.M. Cymbopogon martinii essential oil and geraniol at noncytotoxic concentrations exerted immunomodulatory/antiinflammatory effects in human monocytes. Journal of Pharmacy and Pharmacology 2014, 66, 1491-1496, https://doi.org/10.1111/jphp.12278.

45. Shah, D.; Kamili, A.N.; Wani, A.A.; Majeed, U.; Wani, Z.A.; Sajjad, N.; Ahmad, P. Promoting the accumulation of scopolamine and hyoscyamine in Hyoscyamus niger L. through EMS based mutagenesis. PLOS ONE 2020, 15, https://doi.org/10.1371/journal.pone.0231355.

46. Sahu, R.; Dhongade, H.; Pandey, A.; Sahu, P.; Sahu, V.; Patel, D.; Kashyap, P. Medicinal Properties of Nardostachys jatamansi (A Review). Oriental Journal of Chemistry 2016, 32, 859-66, https://doi.org/10.13005/ojc/320211.

47. Cohen, M. Tulsi - Ocimum sanctum: A herb for all reasons. Journal of Ayurveda and Integrative Medicine 2014, 5, 251-9.

48. Patra, B.; Das, M.; Dey, S. A review on Piper betle L. Journal of Medicinal Plants Studies 2016, 185, 185192.

49. Mbaveng, A.T.; Kuete, V. Chapter 30-Zingiber officinale. In: Medicinal Spices and Vegetables from Africa. Kuete, V. editor. Academic Press; 2017; pp. 627-39, https://doi.org/10.1016/B978-0-12-809286-6.00030-3.

50. Lev-Yadun, S.; Halpern, M. Ergot(Claviceps purpurea)- An aposematic fungus. Symbiosis 2007, 43, 105-8.

51. Ilyas, U.; Katare, D.P.; Aeri, V.; Naseef, P.P.J.P.r. A review on hepatoprotective and immunomodulatory herbal plants. 2016, 10, 66-70, https://doi.org/10.4103/0973-7847.176544.

52. Moon, E.; Lee, S.O.; Kang, T.H.; Kim, H.J.; Choi, S.Z.; Son, M.-W.; Kim, S.Y. Dioscorea Extract (DA9801) Modulates Markers of Peripheral Neuropathy in Type 2 Diabetic $\mathrm{db} / \mathrm{db}$ Mice. Biomolecules \& Therapeutics 2014, 22, 445-452, https://doi.org/10.4062/biomolther.2014.051.

53. Ar, M.; Mk, R.; Devkar, R. Detail Study on Boerhaavia Diffusa Plant for its Medicinal Importance-A Review. Research Jounal of Pharmaceutical Sciences 2012, 1, 28-36.

54. Sunil, M.A.; Sunitha, V.S.; Radhakrishnan, E.K.; Jyothis, M. Immunomodulatory activities of Acacia catechu, a traditional thirst quencher of South India. Journal of Ayurveda and Integrative Medicine 2019, 10, 185-191, https://doi.org/10.1016/j.jaim.2017.10.010.

55. Dohoue, B.; Theophile, O.; Reine, B.; Koudoro, Y.; Agbangnan D, C.P.; Bothon, F.; Alitonou, G.; Avlessi, F.; Dominique, S. Medical benefit, pharmacology and toxicity of jatropha curcas 1. (euphorbiaceae) : a review. International Journal of Advanced Research 2020, 8, 856-864, https://doi.org/10.21474/IJAR01/10374.

56. Rezaeipoor, R.; Saeidnia, S.; Kamalinejad, M. Immunosuppressive activity of Achillea talagonica on humoral immune responses in experimental animals. Journal of Ethnopharmacology 1999, 65, 273-276, https://doi.org/10.1016/s0378-8741(98)00191-3.

57. Narayan, J.; Sah, J.N.; Varshney, V. Chemical constituents of Picrorhiza genus: a review. American Journal of Essential Oil and Natural Products 2013, 1, 22-37.

58. Cheng, Y.B.; Chang, M.T.; Lo, Y.W.; Ho, C.J.; Kuo, Y.C.; Chien, C.T.; Chen, S.Y.; Liou, S.S.; Kuo, Y.H.; Shen, Y.C. Oxygenated Lignans from the Fruits of Schisandra arisanensis. Journal of Natural Products 2009, 72, 1663-1668, https://doi.org/10.1021/np9003678.

59. Allam, G. Immunomodulatory effects of curcumin treatment on murine schistosomiasis mansoni. Immunobiology 2009, 214, 712-727, https://doi.org/10.1016/j.imbio.2008.11.017. 